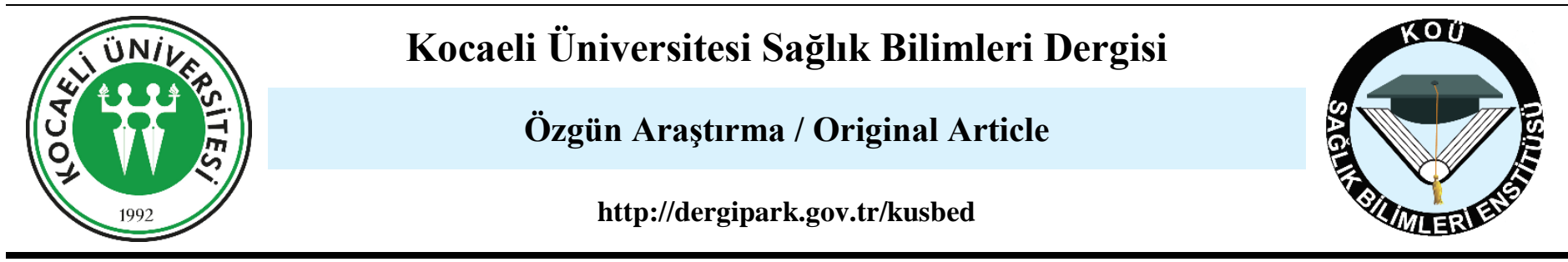

\title{
ADAPTATION OF THE FOOD NEOPHOBIA SCALE INTO TURKISH: VALIDITY AND RELIABILITY STUDY
}

\author{
BESIN NEOFOBISİ ÖLÇEĞIININ TÜRKÇEYE UYARLANMASI: GEÇERLIK VE GÜVENİRLIK ÇALIŞMASI \\ Emre Duman ${ }^{1}$ (iD)Mehtap Akçil Ok ${ }^{2}$,@(iD) Alev Keser ${ }^{3 *}$
}

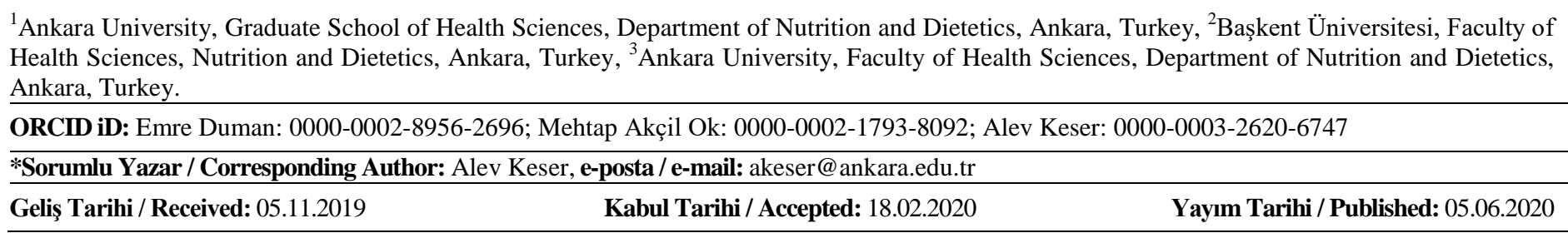

\begin{abstract}
Objective: This study was conducted so at to verify the validity and reliability of "Food Neophobia Scale (FNS)" scale in Turkish.

Methods: The study was conducted on a total of 195 individuals (46.2\% is male, $53.8 \%$ is female) aged between 19 and 64 (38.6 \pm 13.51 ) who accepted to voluntarily participate in the study in Ankara. While the demographical characteristics of the patients were questioned in the first stage, the 10-item FNS form having been translated into Turkish was used.

Results: In the study, the existence of sufficient correlation among the items in the scale and the adequacy of sample size was examined; it was determined that the sample size was sufficient $(\mathrm{KMO}=0.78)$ and there was a sufficient relationship between the items for factor analyzes $(\chi 2=142.502 ; p<0.05)$. In the assessment of fit of the scale, good fit cover index of $\chi 2$ was used and consequently the scale was found to have a good fit. The Cronbach alpha internal consistency coefficient was found to be as 0.614 for the integrity of FNS. The Adjusted Goodness of Fit Index (AGFI) was found to be 0.92 . The fact that this value is over 0.90 proves the model to have a good fit.

Conclusion: The findings being acquired as a result of the all statistical analyzes have shown that the FNS adapted to Turkish is a reliable and valid measuring tool which can be used in Turkey. It is thought that FNS adapted to Turkish can contribute to the studies for research of food neophobia.
\end{abstract}

Keywords: Eating behavior; food neophobia; reliability.

\section{$\ddot{\mathbf{O z}}$}

Amaç: Bu çalışma; "Food Neophobia Scale (FNS)" ölçeğinin Türkçe geçerlik ve güvenirliğini gerçekleştirmek amacıyla yapılmıştır.

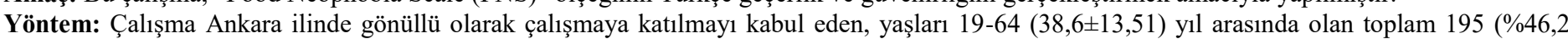
erkek, \%53,8 kadın) birey üzerinde yürütülmüştür. İlk aşamada hastaların demografik özellikleri sorgulanırken; 2 . aşamada 10 maddelik FNS'nin Türkçeye çevrilmiş formu kullanılmıştır.

Bulgular: Çalışmada ölçekteki maddeler arasında yeterli korelasyonun olup olmadığı ve örneklem büyüklüğünün yeterliliği incelenmiş; örneklem büyüklüğünün yeterli olduğu $(\mathrm{KMO}=0,78)$ ve maddeler arasında faktör analizi yapılabilecek yeterli düzeyde ilişkinin olduğu saptanmıştır $(\chi 2=142,502 ; p<0,05)$. Ölçeğin uyumunun değerlendirilmesinde $\chi 2$ iyi uyum indeksi kullanılmış ve bunun sonucunda ölçeğin iyi derecede bir uyuma sahip olduğu saptanmıştır. FNS'nin bütünlüğü için Cronbach alfa iç tutarlılık katsayısı 0,614 olarak bulunmuştur. Tüm maddelerin toplam puan ile korelasyonu pozitif ve 0,40'ın üzerindedir. Düzeltilmiş İyi Uyum İndeksi (Adjusted Goodness of Fit Index-AGFI) 0,92 olarak bulunmuştur. Bu değerin 0,90'ın üzerinde olması modelin iyi uyumlu olduğunu göstermektedir.

Sonuç: Yapılan tüm istatistiksel analizler sonucunda elde edilen bulgular Türkçeye uyarlanan FNS'nin Türkiye'de kullanılabilir geçerli ve güvenilir bir ölçme aracı olduğunu göstermiştir. Türkçe'ye uyarlanan FNS'nin besin neofobisinin araştırılmasına yönelik çalışmalara katkı sağlayacağı düşünülmektedir.

Anahtar Kelimeler: Yeme alışkanlığl; besin neofobisi; güvenirlik. 


\section{Introduction}

Nowadays although it is easier to reach convenience food or food belonging to several different cultures, consuming new nutriments has different antecedents and consequences. Especially in recent years, people are suggested to avoid new and unknown foods. ${ }^{1-3}$

Food neophobia is defined as the fear of eating new or unknown foods, in other words, the foods which have not been previously consumed. ${ }^{4}$ The food neophobia defined as reluctance to eat and avoidance of foods with unknown content and taste which have not been previously tested can be also expressed as an evolutionary survival and defense mechanism having been developed by individuals to protect against toxic chemicals and microorganisms. ${ }^{5,6}$ This effect can be observed particularly in childhood a result of not liking the sensorial properties of a food. ${ }^{7}$

Food neophobia in both adults and children varies depending on environmental factors such as age, education, degree of urbanization, income level and culture. ${ }^{8-10}$ Among these factors, age in particular is an important determinant of food neophobia. It is thought that individuals who are more affected by educational and cultural factors may be more resistant to adopting new eating behaviors as they get older. $^{11}$

The food neophobia is significant in terms of healthy nutrition and was shown to affect the quality and diversity of the diet. The energy intake and diet quality of the individuals with neophobia are stated to be lower than those of the individuals with neophilism. ${ }^{12,13}$ Therefore, it is considered that taking nutritional neophobia into consideration may be an important necessity, especially in cases requiring nutritional therapy. ${ }^{12}$

Food Neophobia Scale (FNS) was developed by Pliner and Hobden in 1992 as a psychometric tool to identify the food neophobia. ${ }^{4}$ This scale consists of a total of 10 items; 5 positive and 5 negative items about food and status of food consumption. FNS is assessed with a Likert scale of 7 (7 points: Strongly agree, 6 points: Agree, 5 points: Agree very little, 4 points: Indecisive, 3 points: Disagree very little, 2 points: Disagree, 1 point: Strongly disagree). The FNS score is a score in the range of 10 to 70 points, which is calculated by reversing the negative items $1,4,6,9$ and 10 on the scale.

The FNS scale, which is used to measure food neophobia known as fear of eating not previously consumed foods, was adapted into many different languages. ${ }^{14-16}$ This study was carried out in order to adapt the FNS scale to Turkish and to conduct its validity and reliability studies as it was thought to contribute to the studies to determine food neophobia.

\section{Methods}

\section{Sampling and Procedure}

The sample of the study constitutes a total of 195 individuals $(46 \%$ is male and $54 \%$ is female) with the age range from 19 to $64(38.6 \pm 13.5)$ who accepted to voluntarily participate in the study in Ankara between the dates of December, 2017 and February, 2018. The sample size was determined based on the knowledge that it is required to be applied to at least 5-10 times more than the number of items in the scale so as to perform all these necessary factors. ${ }^{17}$

A questionnaire form consisting of 30 questions was prepared by the researchers to determine the sociodemographic characteristics of the individuals. The data were obtained by face-to-face interview technique.

\section{Food Neophobia Scale}

One-dimensional food neophobia scale consists of 10 items. All of the items are 7-point Likert type and answers are 7 points $=$ Strongly agree, 6 points $=$ Agree, 5 points $=$ Agree very little, 4 points $=$ Indecisive, 3 points $=$ Disagree very few, 2 points $=$ Disagree, 1 point $=$ Strongly disagree .

\section{Methodology}

In order to adapt the scale to Turkish, FNS consisting of 10 items was firstly translated from English into Turkish and later from Turkish into English by three faculty members with English language proficiency from the Department of Nutrition and Dietetics under Faculty of Health Sciences at Ankara University.

The consistency was crosschecked between the translations by faculty members specialized in their field and the Turkish scale was created after the necessary corrections in terms of meaning and grammar were made. This scale was presented to the opinions of 6 faculty members working in the Department of Nutrition and Dietetics of Faculty of Health Sciences at Ankara University. The last form of the scale was given considering the suggestions of the faculty members.

After the scales were translated, a preliminary poll was carried out on 20 persons between 19 and 64 years in order to be able to evaluate whether the scales are understandable and determine the mean application duration. As a result of this preliminary survey, it was concluded that majority of the participants had difficulty in understanding the word of "ethnic" being translated as "etnik". Therefore, the word of "ethnic" was translated as "different country" by receiving the specialist opinion. It was determined that there is no problem in understanding the final version of the translation (Table 1), and answering the questionnaire and the scale takes 10-15 minutes on average. The data received from the study having been conducted as a preliminary poll were not included in this study.

Table 1. Items of FNS in English and Turkish languages.

\begin{tabular}{l|l}
\hline English Items & Turkish Items \\
\hline $\begin{array}{l}\text { 1. (R) I am constantly sampling } \\
\text { new and different foods }\end{array}$ & $\begin{array}{l}\text { 1. (R) Sürekli yeni ve farklı besinler } \\
\text { denerim }\end{array}$ \\
\hline 2. I don't trust new foods & 2. Yeni besinlere güvenmem \\
\hline $\begin{array}{l}\text { 3. If I don't know what a food is, I } \\
\text { won't try it }\end{array}$ & $\begin{array}{l}\text { 3. İerisinde ne olduğunu } \\
\text { bilmediğim bir besini denemem }\end{array}$ \\
\hline 4. (R) I like foods from different & $\begin{array}{l}\text { 4. (R) Farklı ülkelerin besinlerini } \\
\text { cultures }\end{array}$ \\
\hline 5. Ethnic food looks weird to eat & $\begin{array}{l}\text { 5. Farklı ülkelerin besinlerini } \\
\text { tüketmek çok tuhaf gelir }\end{array}$ \\
\hline 6. (R) At dinner parties, I will try & $\begin{array}{l}\text { 6. (R) Yemekli davetlerde yeni bir } \\
\text { besin denerim }\end{array}$ \\
\hline 7. I am afraid to eat things I have & $\begin{array}{l}\text { 7. Daha önce hiç tüketmediğim } \\
\text { besinleri tüketmekten korkarım }\end{array}$ \\
never had before & $\begin{array}{l}\text { 8. Tüketeceğim besinler konusunda } \\
\text { çok seçiciyim }\end{array}$ \\
\hline 8. I am very particular about the \\
foods I eat & 9. (R) Neredeyse her şeyi yerim \\
\hline 9. (R) I will eat almost anything & $\begin{array}{l}\text { 10. (R) Farklı ülkelerin restoranlarını } \\
\text { denemeyi severim }\end{array}$ \\
\hline 10. (R) I like to try ethnic \\
restaurants
\end{tabular}

$\mathrm{R}$ : reversed items.

Data Analysis

The statistic software program of SPSS Statistical Package for Social Sciences Version 22 was used for the statistical analyzes of the data obtained from the study. The confirmatory factor analyzes method made in order to analyze the compliance of sub-dimensions of the scale with theoretical model was carried out by benefitting from AMOS Version 22 program. Quantitative variables obtained 
by measurement were presented with median, mean, standard deviation, minimum and maximum values. Frequency and percentage values were used for the presentation of qualitative variables, Kolmogorov-Smirnov test was used to examine the appropriateness of quantitative variables to normal distribution. The relation between the variables was examined with "Pearson Correlation Coefficient".

The sample number and correlation sufficiency, which is a prerequisite to carry out the validity and reliability analyzes of the scale, were analyzed. With Kaiser-Meyer-Olkin (KMO), the adequacy of sample size and with Bartlett sphericity test, the existence of sufficient correlation among the items required for factor analyzes to be implemented were examined. The coherence of FNS scale having been adapted to Turkish language with the original scale was evaluated with confirmatory factor analyzes. As fit indicators, the chi-square $\left(\chi^{2}\right)$ good fit index, the adjusted goodness of fit index (AGFI)], root mean square residual (RMR) and root mean square error of approximation (RMSEA) were used.

The analyzes of the structural validity was performed by explanatory factor analyzes, and the analyzes of reliability (internal consistency) was performed by reliability and item analyzes (Cronbach alpha coefficient). In order to prove the validity of the factor dimensions existing in the theory, the confirmatory factor analyzes was applied. The significance level in all statistical analyzes was accepted as $p<0.05$.

\section{Results}

\section{Explanatory Factor Analyzes of Food Neophobia Scale}

In the study, the existence of correlation among the items which are prerequisite for factor analyzes was examined with Bartlett sphericity test, while the adequacy of sample size was analyzed with KMO. According to this; sampling adequacy statistic results show that the sample size is sufficient $(\mathrm{KMO}=0.78)$. The fact that $\mathrm{KMO}$ value $(0.78)$ is bigger than 0.50 proves the adequacy of sample size of that scale data. Moreover, according to the Bartlett sphericity test, it was determined that there was a relation between the items at a sufficient level to conduct a factor analyzes $(\chi 2=142.502 ; p<0.05)$. The scale was accepted to be unidimensional as a result that the first factor (component) explained $34 \%$ of the variance of total scale score. The fact that all these factor loadings are above 0.40 indicates that the scale has construct validity and no item should be removed from the scale. The explanatory factor analyzes results of FNS scale are shown in Table 2.

\section{Confirmatory Factor Analyzes}

In the study, for the confirmatory construct validity of FNS scale, the structure with single factor was tested based on the original. The compliance of the collected data with the desired model was analyzed by structural equation model. The fit statistics of the model is demonstrated in Table 3 and the fit scheme is given in Figure 1.
Table 2. Explanatory factor analyzes results of Food Neophobia Scale*

\begin{tabular}{ll}
\hline Items & $\begin{array}{l}\text { Factor 1 } \\
\text { Food Neophobia }\end{array}$ \\
\hline FNS1 & 0.527 \\
FNS2 & 0.606 \\
FNS3 & 0.609 \\
FNS4 & 0.819 \\
FNS5 & 0.564 \\
FNS6 & 0.544 \\
FNS7 & 0.791 \\
FNS8 & 0.479 \\
FNS9 & 0.821 \\
FNS10 & 0.807 \\
\hline Eigenvalue & 3.404 \\
The percentage of variance explanation & 34.041 \\
\hline
\end{tabular}

*The values in the table are factor loadings. FNS: Food Neophobia Scale

Table 3. Fit statistics for the Turkish versions of Food Neophobia Scale.

\begin{tabular}{lll}
\hline Fit indices & Criteria & Turkish versions of FNS \\
\hline$\chi^{2} / \mathrm{sd}$ & $3<\chi^{2} / \mathrm{sd}<4-5$ & 4.05 \\
AGFI & $\geq 0.90$ & 0.92 \\
RMR & $\leq 0.05$ & 0.035 \\
RMSEA & $0.06-0.08$ & 0.063 \\
\hline
\end{tabular}

Different indexes can be utilized in the assessment of model fit. The scale is seen to have a notably good fit considering the chi-square $\left(\chi^{2}\right)$ goodness fit index used in this study. Additionally, Adjusted Goodness of Fit Index-AGFI was found to be 0.92 . That this value is above 0,90 indicates that the model has a goodness fit (Table 3).

Likewise, that Root Mean Square Residual (RMR) is less than 0.05 and Root Mean Square Error of Approximation (RMSEA) is less than 0.08 indicates that the model has a goodness fit. Hence, the statistical results found in food neophobia scale indicate the acceptability and applicability of the adaptation of scale to Turkish language (Table 3).

\section{Results of Reliability Analyzes}

The level of internal consistency among the items of FNS, item total correlations and Cronbach alpha internal consistency coefficients are demonstrated in Table 4. According to it, the Cronbach alpha internal consistency coefficient was found to be 0.614 for the integrity of FNS. Cronbach alpha internal consistency coefficient values between 0 and 1 . That this coefficient approaches to 1 shows that the scale is perfectly reliable. As it can be seen in Table 4 , the correlation of all items with total score is positive and above 0.40 . It means that the scale can measure the food neophobia as a whole. Accordingly, that none of the items should be removed from the scale can be seen from the Cronbach alpha internal consistency coefficient which was calculated after removal of item (Table 4). 


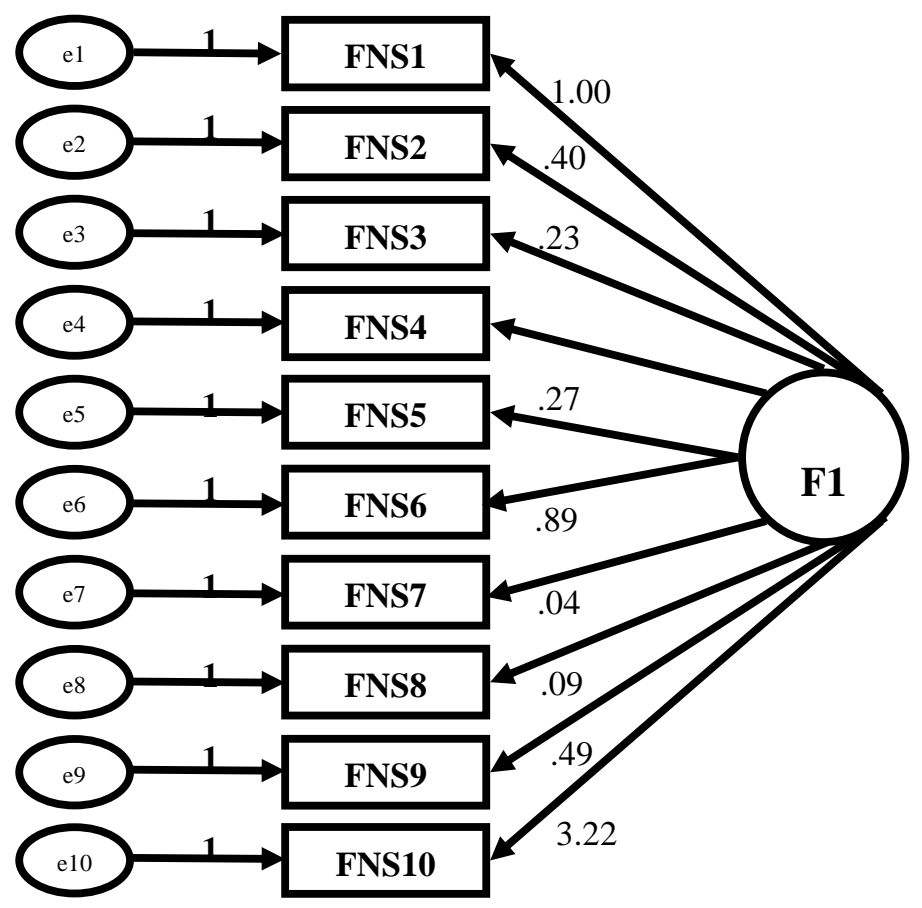

Figure 1. Compliance of Food Neophobia Scale between confirmatory factor analyzes and Single Factorial Model.

Table 4. Analysis of the scale factor of FNS reliability results.

\begin{tabular}{lll}
\hline Factor & $\begin{array}{l}\text { Corrected-item total } \\
\text { score correlation }\end{array}$ & $\begin{array}{l}\text { Cronbach's Alpha if } \\
\text { item deleted }\end{array}$ \\
\hline FNS1 & 0.274 & 0.591 \\
FNS2 & 0.321 & 0.581 \\
FNS3 & 0.303 & 0.585 \\
FNS4 & 0.232 & 0.601 \\
FNS5 & 0.299 & 0.586 \\
FNS6 & 0.262 & 0.594 \\
FNS7 & 0.542 & 0.525 \\
FNS8 & 0.271 & 0.592 \\
FNS9 & 0.118 & 0.629 \\
FNS10 & 0.265 & 0.594 \\
\hline
\end{tabular}

FNS: Food Neophobia Scale

\section{Evaluation of Food Neophobia Scale}

The minimum and maximum scores which can be obtained from food neophobia scale is seen in Table 5. It is evaluated with a single factor and 10-item FNS 7 Likert scale. The options include: "Strongly Agree" is 7 points, "Agree" is 6 points, "Agree very little" is 5 points, "Indecisive" is 4 points, "Disagree very little" is 3 points, "Disagree" is 2 points, and "Strongly Disagree" is 1 point. As the score of the individuals in the scale increases, the fear of eating new foods increases, as well. According to this, minimum score and maximum score from the food neophobia scale can be 10 and 70 successively. The minimum and maximum scores of food neophobia scale according to gender and age groups are shown in Table 5. In this study, the food neophobia score of the participants is 15 in minimum and 63 at maximum. When the scale is evaluated, as the score from the scale increases, food neophobia increases, as well. According to the gender, mean (39.79) and median (39.00) food neophobia scores were found to be similar. Yet, food neophobia scores differ according to age groups. There was found a positive and moderate statistically significant correlation between age and food neophobia scores $(\mathrm{r}=$ $0.271 ; p<0.05)$. Particularly, as the age group raises, the score of food neophobia increases.
Table 5. The minimum and maximum scores of food neophobia scale according to gender and age groups.

\begin{tabular}{lcccccc}
\hline Gender & n & Min & Max & Median & Mean & SD \\
\hline Male & 90 & 15 & 61 & 40 & 39.09 & 9.12 \\
Female & 105 & 22 & 63 & 39 & 40.39 & 7.67 \\
\hline \multirow{2}{*}{ Age Groups } & & & & & & \\
\hline $19-30$ & 70 & 15 & 58 & 38 & 37.37 & 8.05 \\
$31-40$ & 36 & 18 & 60 & 38 & 38.08 & 9.69 \\
$41-50$ & 39 & 28 & 61 & 41 & 42.41 & 7.87 \\
$51-64$ & 50 & 28 & 63 & 42 & 42.36 & 6.97 \\
\hline $\mathrm{r}=0.271^{*} ;$ & & & & & & \\
$\mathrm{p}=0.0001$ & & & & & & \\
Total & 195 & 15 & 63 & 39 & 39.79 & 8.37 \\
\hline
\end{tabular}

* Pearson's correlation coefficient between age and food neophobia score

\section{Discussion}

In international literature, FNS is widely used in detection of food neophobia. ${ }^{18,19}$ There is no comprehensive, valid and reliable measuring tool concerning this issue developed in Turkey. Therefore; in this study, the validity and reliability analyzes of FNS in Turkish language was performed in determination of food neophobia among adults.

In the study, the factor and reliability analyzes of the scale was firstly carried out. According to this, the existence of sufficient correlation between the items in the scale and adequacy of sample size were studied; the sample size was established to be adequate $(\mathrm{KMO}=0.78)$ and there was a sufficient relation found among the items to make factor analysis $\left(\chi^{2}=142.502 ; p<0.05\right)$. In the assessment of scale fit, $\chi^{2}$ goodness fit index was used and as a result, the scale was found to have a goodness fit.

The level of internal consistency among the items of FNS were examined with item total correlations and Cronbach alpha internal consistency coefficients and according to it, the Cronbach alpha internal consistency coefficient was found to be 0.614 for the integrity of FNS. Cronbach alpha internal consistency coefficient values between 0 and 1 . That this coefficient approaches to 1 shows that the scale is perfectly reliable. Besides, the correlation of all items with total score was found to be positive and above 0.40 . It means that the scale can measure the food neophobia as a whole. In addition to all these, the lowest and highest values for the scores to get from FNS are between 10 and 70. In the assessment of the scale, it is remarked that as the score from the scale increases, food neophobia increases, as well.

In the other studies having been conducted, FNS was adapted to different languages and internal consistency was analyzed. Fernández-Ruiz et al. ${ }^{14}$ adapted the FNS to Spanish and found the Cronbach alpha internal consistency coefficient as 0.82 . They concluded that the mean food neophobia score in Spain was 31.74, and age had a significant impact on food neophobia. In this study, Cronbach alpha internal consistency coefficient was found to be 0.614 . The mean food neophobia score was found to be 39.79 and age was concluded to significantly influence food neophobia $(p<0.05)$. Ribeiro de Andrade Previato and Herman Behrens ${ }^{16}$ adapted it to Brazilian Portuguese and found Cronbach alpha internal consistency coefficient as 0.916 . In addition, they concluded that $17.5 \%$ of the participants were neophobic.

As a conclusion, FNS is a scale used in identification of food neophobia. The findings obtained as a result of all analyzes have shown that the scale adapted from FNS to 
Turkish is valid and reliable measuring tool which can be used in Turkey.

It is suggested that diet quality and food variety, which are important components of healthy nutrition, are affected by food neophobia. Therefore, it is important to identify individuals with food neophobia throughout the country. However, there is no Turkish assessment tool for food neophobia. In this context, incidence of food neophobia and its effects on health will be evaluated by introducing Turkish validity and reliability scale into literature. In this context, Turkish validity and reliability of food neophobia scale will be added to the literature and incidence of food neophobia and its effects on health will be evaluated. In addition, necessary solution proposals will be obtained in cooperation with responsible stakeholders.

\section{Conflict of Interest}

No conflicts of interests to disclose.

\section{Compliance with Ethical Statement}

A written consent form was obtained from the individuals stating that they participated in the study voluntarily. "Ethics Committee Approval" numbered 56786525-050.04.04 / 21592 and dated 03/21/2019 was obtained from Ankara University, Non-Clinical Studies Ethical Committee to carry out this study.

\section{Financial Disclosure/Funding}

The author(s) received no specific funding for this work.

\section{Author Contributions}

ED: collected data and contributed data; MAO: performed analysis; AK: conducted and designed the research; ED, MAO, AK: wrote the manuscript; All authors: read and approved the manuscript.

\section{References}

1. Raudenbush B, Schroth F, Reilley S, Frank RA. Food neophobia, odor evaluation and exploratory sniffing behavior. Appetite. 1998;31:171-183. doi:10.1006/appe.1998.0161.

2. Russell CG, Worsley A. A population-based study of preschoolers' food neophobia and its associations with food preferences. J Nutr Educ Behav. 2008;40:11-19. doi:10.1016/j.jneb.2007.03.007.

3. Skinner JD, Carruth BR, Bounds W, Ziegler PJ. Children's food preferences: a longitudinal analysis. J Am Diet Assoc. 2002;102:1638-1647. doi: 10.1016/S0002-8223(02)90349-4.

4. Pliner P, Hobden K. Development of a scale to measure the trait of food neophobia in humans. Appetite. 1992;19:105-120. doi:10.1016/0195-6663(92)90014-W.

5. Galloway AT, Lee Y, Birch LL. Predictors and consequences of food neophobia and pickiness in young girls. $J$ Am Diet Assoc. 2003;103:692-698. doi:10.1053/jada.2003.50134.

6. Dovey TM, Staples PA, Gibson EL, Halford JC. Food neophobia and 'picky/fussy'eating in children: a review. Appetite. 2008;50:181-193. doi:10.1016/j.appet.2007.09.009.

7. Capiola A, Raudenbush B. The effects of food neophobia and food neophilia on diet and metabolic processing. Food Nutr Sci. 2012;3:1397-1403. doi:10.4236/fns.2012.310183.

8. Koivisto UK, Sjödén PO. Food and general neophobia in Swedish families: Parent-child comparisons and relationships with serving specific foods. Appetite. 1996;26:107-118. doi:10.1006/appe.1996.0009.

9. Meiselman HL, King SC, Gillette M. The demographics of neophobia in a large commercial US sample. Food Qual Prefer. 2010;21:893-897. doi:10.1016/j.foodqual.2010.05. 009 .
10. Ritchey PN, Frank RA, Hursti UK, Tuorila H. Validation and cross-national comparison of the food neophobia scale (FNS) using confirmatory factor analysis. Appetite. 2003;40:163173. doi:10.1016/S0195-6663(02)00134-4.

11. Roßbach S, Foterek K, Schmidt I, Hilbig A, Alexy U, Food neophobia in German adolescents: Determinants and association with dietary habits. Appetite. 2016;101:184-191. doi:10.1016/j.appet.2016.02.159.

12. Falciglia GA, Couch SC, Gribble LS, Pabst SM, Frank R. Food neophobia in childhood affects dietary variety. $J \mathrm{Am}$ Diet Assoc. 2000;100:1474-1481. doi:10.1016/S00028223(00)004 12-0.

13. Cooke L, Carnell S, Wardle J. Food neophobia and mealtime food consumption in 4-5 year old children. Int J Behav Nutr Phys Act. 2006;3:14. doi:10.1186/1479-5868-3-14.

14. Fernández-Ruiz V, Claret A, Chaya C. Testing a Spanishversion of the food neophobia scale. Food Qual Prefer. 2013;28:222-225. doi: 10.1016/j.foodqual.2012.09.007.

15. Paupério A, Severo M, Lopes C, Moreira P, Cooke L, Oliveira A. Could the Food Neophobia Scale be adapted to pregnant women? A confirmatory factor analysis in a Portuguese sample. Appetite. 2014;75:110-116. doi:10.1016/j.appet.2013. 12.023.

16. Ribeiro de Andrade Previato HD, Behrens JH. Translation and validation of the Food Neophobia Scale (FNS) to the Brazilian Portuguese. Nutr Hosp. 2015;32:925-930. doi:10.3305/nh.20 15.32.2.9108.

17. Tinsley HE, Tinsley DJ. Uses of factor analysis in counseling psychology research. J Couns Psychol. 1987;34:414. doi:10.10 37/0022-0167.34.4.414.

18. Rigal N, Frelut ML, Monneuse MO, Hladik CM, Simmen B, Pasquet P. Food neophobia in the context of a varied diet induced by a weight reduction program in massively obese adolescents. Appetite. 2006;46:207-214. doi:10.1016/j.a ppet.2006.01.001.

19. Stratton LM, Vella MN, Sheeshka J, Duncan AM. Food neophobia is related to factors associated with functional food consumption in older adults. Food Qual Prefer. 2015;41:133140. doi:10.1016/j.foodqual.2014.11.008. 